\title{
技術報告
}

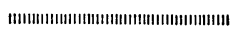

\section{血中トリプシン測定用ラジオイムノアッセイキットの 臨床的有用性}

\author{
金森勇雄, 中野 哲, 古川雅一, 奥村恭己, 确口ちつ’子, 柳瀬みき子, 小野木満照 \\ 大垣市民病院放射線科特殊放射線センター \\ 503 大垣市南頓町4-86 \\ 1988年 4 月13日受理
}

Key Words: trypsin, radioimmunoassay, pancreatic diseases

\section{1. はじめに}

膵から血中に逸脱する酵素の臨床的意義は大きく， 血清および尿アミラーゼ1)，血清リパーゼ等2)の検索 は頻回に行われている。しかし，トリプシンはアミラ 一ゼやリパーゼに比べ脺特異性は高いと推定されてい るが，血液中の $\alpha_{1}$-antitrypsin， $\alpha_{2}$-microglobulin など の酵素活性阻害物質やトロンビン, プラスミン, カリ クレインなど，類似の活性を示す蛋白分解酵素が血清 トリプシンの酵素活性測定を困難としていた ${ }^{3)} 。$

放射免疫測定(RIA) は免疫学的活性を利用すること から, 酵素活性測定と異なり，共存する活性類似酵素 や阻害物質の影響が少なく，血清トリプシンを特異的 に測定できるとされている3゙。われわれは血中トリプ シン濃度が定量的に測定可能なRIAキットを入手する 機会を得たので, このキットの基礎的検討を行った。

\section{2. 対象および方法}

大垣市民病院消化器科を受診した, 膵性糖尿病 10 例, 急性膵炎20例, 慢性膵炎 9 例, 膵がん23例の計62 例を対象とした。また，対照群は当院職員44例の早朝 空腹時血清である。採血は肘静脈を原則とし, 可及的 速やかに血清を分離し $-20^{\circ} \mathrm{C}$ で保存, 測定時に室温 にもどし測定した。

測定方法は, RIAの二抗体法で被検血清または標準 血清 $(0.1 \mathrm{ml})$ に ${ }^{125} \mathrm{I}$-標識トリプシン $(0.2 \mathrm{ml})$ を加え インキュペーション(室温, 10-24時間) 後にトリプシ ン抗体液 $(0.1 \mathrm{ml})$ を添加し, 再度インキュベーショ ン(室温, 3-5時間)する。ついで, 洗浄液 $1.0 \mathrm{ml}$ を加 え, 遠心分離（2500 rpm, 20-30分）し，上清を除去 した放射能よりトリプシン值を標準曲線から換算する 方法である。

\section{3. 結 果}

$3 \cdot 1$ 標準曲線

10回測定で各測定濃度における結合率 $(B / T \%)$ の mean \pm S.D. は, $78 \mathrm{ng} / \mathrm{ml}$ で $48.5 \pm 4.7 \%, 1250 \mathrm{ng} /$ $\mathrm{ml}$ で $11.0 \pm 2.0 \%$ で，良好な勾配の標準曲線が得ら れた。また，各測定濃度における変動係数 (C.V.) は 9.6-18.4\% の間にあり，ほぼ満足すべき值が得られ た (Fig. 1)。

$$
\begin{aligned}
& 3 \cdot 2 \text { インキュベーション温度 } \\
& \text { インキュベーション設定温度の変動が } B / T(\%) \text { に }
\end{aligned}
$$
及ぼす影響について検討した（Fig. 2)。

第一反応は, 設定温度 $25^{\circ} \mathrm{C}$ が他の設定温度 4,37 , $45{ }^{\circ} \mathrm{C}$ に比べ最も高い $B / T(\%)$ を示した。また，第二 反応は 4-25 Cの間でほぼ安定したプラトー状態を示

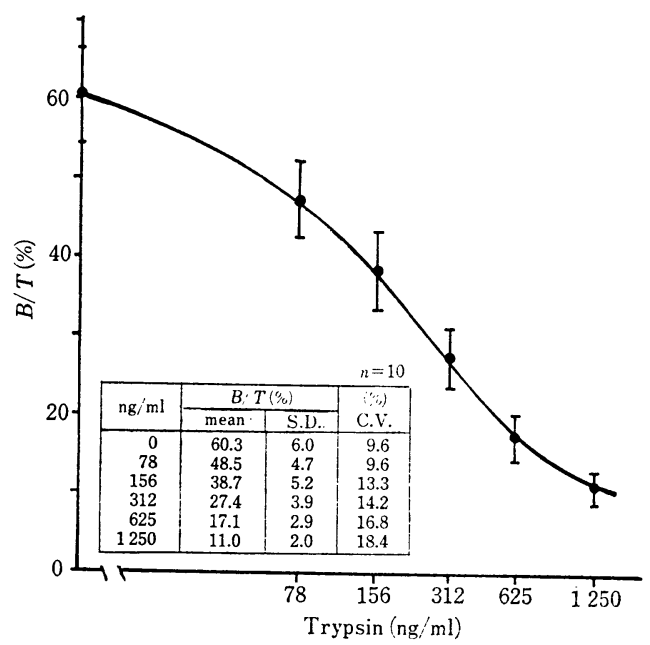

Fig. 1 Standard curve. 

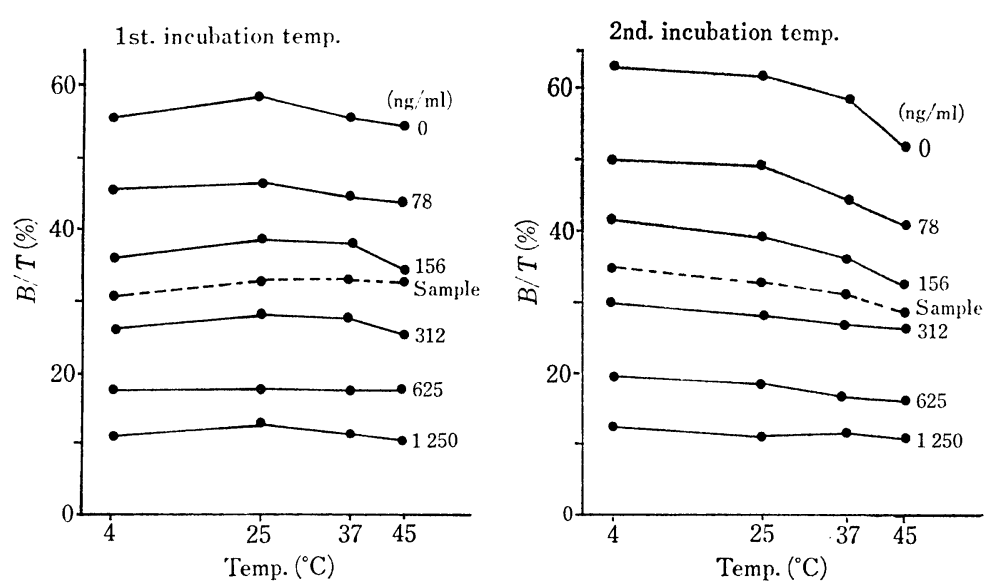

Fig. 2 Incubation temperature.
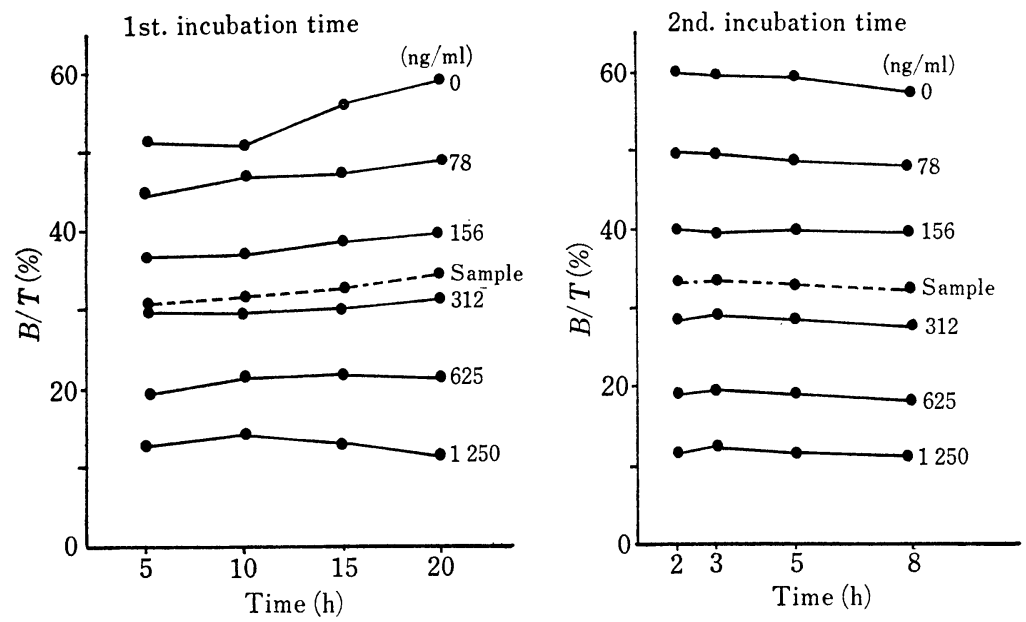

Fig. 3 Incubation time.

すが， 37,45 Cでは急激なる $B / T(\%)$ の低下を示す。

\section{$3 \cdot 3$ インキュベーション時間}

インキュベーション設定時間の変動が $B / T(\%)$ 飞

及ぼす影響について検討した（Fig. 3)。

第一反応は，設定時間が他の設定時間 $5,10,15$ 時間 に比べ最も高い $B / T(\%)$ を示した。また，第二反応 は 2-3 時間の間は不安定状態を示すが，3-8 時間の間 はほぼ安定したプラトー状態を示した。

\section{$3 \cdot 4$ 再現性}

同時, 日差再現性ともに各被検血清 5 回測定による C.V.について検討した。同時再現性は3.17-6.94\%， 日差再現性は 3. 88-6.86\%の間にあり浪満足すべき 值であった。
$3 \cdot 5$ 添加回収率

各被検血清の添加回収率は 100.9-104.6\%, 99.1-100.5\% の間にあり, 平均値は 102.9 \%，99.8\%となり，ほぼ満足 すべき值であった。

\section{$3 \cdot 6$ 希釈試験}

2 被検血清を生理食塩水で $2,4,10$ 倍に希釈し, 理論 值と希釈值との聎離, および 希釈効果を検討した。

2 被検血清の希釈値は理論 值とほぼ一致し, 希釈曲線は 原点に集束する直線性を示 し，良好な希釈効果を示し た。

$3 \cdot 7$ 血中トリプシンとエ ラスターゼ-1との相関

両者間の相関関係は $r=$ $0.889(p<0.01)$ で有意なる 正の相関を示す (Fig. 4)。

\section{8 正常域}

当院職員早朝空腹時血清の 血中トリプシン值は 90-540 $\mathrm{ng} / \mathrm{ml}$ の間に分布し, mean \pm S.D.は303. $4 \pm 112.3 \mathrm{ng} / \mathrm{ml}$ （男性 $330.9 \pm 107.0 \mathrm{ng} / \mathrm{ml}$, 


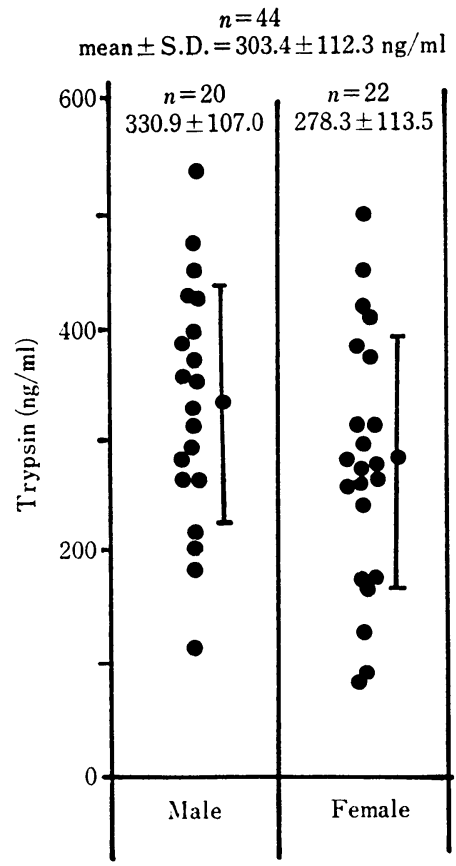

Fig. 5 Normal subjects.

女性278.3土113. $5 \mathrm{mg} / \mathrm{ml}$ ) であった。男性は女性に比 ベ僅かに高い値を示す傾向にあった（Fig. 5)。

\section{9 膵各種疾患の血中トリプシン値}

糖尿病 10 例, 慢性腈炎 9 例はいずれも $500 \mathrm{ng} / \mathrm{ml}$ 以 下であった。急性膵炎では 20 例中 5 例 (25\%) が500 $\mathrm{ng} / \mathrm{ml}$ 以下, 500-1250 ng/ml の間が 6 例 (30\%), $1250 \mathrm{ng} / \mathrm{ml}$ 以上が 9 例 (45\%) であった。また，膵が んは23例中 3 例 $(13 \%)$ か $500 \mathrm{ng} / \mathrm{ml}$ 以上を示した。 急性膆炎は他の膵疾患に比べ顕著に高值を示す症例が 多かった（Fig.6）。

\section{4. 考察}

トリプシンは至適 pH 8.0-9.0の代表的な膵外分泌 酵素 (蛋白分解酵素) で, Kvehne が命名し Northrop and Kunity が結晶化し，化学的にはアミノ酸 201 個 からなる分子量約 22900 の蛋白である3゙。トリプシン の一部は腸管から排泄されるが，膵細胞から間質液を 通り血墏中に入るものもあり，よって血中トリプシン の測定は膵疾患の診断，とくに急性膵炎の診断および 経過観察に有用であるとされている11-3)。近年酵素法 で測定できなかったトリプシンと，その前駆物質トリ プシノーゲンに対してのみに特異的な抗体を用いた RIA キットが開発されて以来安易に血中トリプシンの 測定が可能となった ${ }^{4), 5) 。 ~}$

われわれが検討したRIAキットは，トリプシンを蛋 白量として直接，また特異的に測定する方法で， B · $\mathrm{F}$ 分離は二抗体法を用いている。

本法の標準曲線は急峻なる曲線であるが，C.V.が 10\%を超える。一般的に RIA キットは $10 \%$ 以下であ り, やや坌るものと考えられ, 今後の検討が待たれ る。しかし, 再現性は日差, 同時再現性ともに $7.0 \%$ 以下, 添加回収率も列％以内であることから, 血中 トリプシン測定への直接的な影響は少なく, 測定値に 変化を及ぼすことはないと考えられる。

インキュベーション温度の設定は室温であること が，手技的に最も簡便である。本法は一般的な室温の $25{ }^{\circ} \mathrm{C}$ 前後で安定したプラトー状態を示すことから, 術者は容易にインキュペーション温度の設定ができ る。さらに，インキュベーション時間は第一反応，第 二反応ともに僅かな時間変動では測定值に変化が現わ れないほぼ安定したプラトー状態の範囲で測定でき る。このことは, 術者の操作性に優れたキットである と考觉らる。

また，希釈曲線は原点に集 束する優れた希釈効果が示さ れることから，高濃度の血中 トリプシンも問題なく測定で き得ると考える。

本法とェラスターゼ-1は有 意な相関性が認められ れわれの検討でも $r=0.889$ と 優れていた。このことはトリ プシンはエラスターゼ-1 ともに膵疾患のスクリーニン グ法に有用性があると考えら

Fig. 6 Serum trypsin concentration of pancreatic diseasis $(n=62)$. 
れる。

一方，血中トリプシンの正常域はヘキスト社のキッ トでは $100-500 \mathrm{ng} / \mathrm{ml}^{3)}, 78-580 \mathrm{ng} / \mathrm{ml}^{5}$, cis-Sorin $15-$ $43 \mathrm{ng} / \mathrm{ml}^{4)}$, ミドリ十字 $29.0 \pm 16.6 \mathrm{ng} / \mathrm{ml}^{6)}$, と報告さ れている。開発社により大きな差異がある。本法はへ キスト社であるからほぼ 100-500 $\mathrm{ng} / \mathrm{ml}$ の範团が正常 域であると考兄られる。

さらに，血清トリプシンの膵疾患に括ける動態は従 来の報告とほぼ同様な傾 向にある。急性膵炎では著 明な上昇 ${ }^{5)}$ ，高度慢性膵炎扣よび膵がん進行例は低 下 $^{5), 6)}$ ，慢性再発性膵炎の発作時ないし膵炎を随伴し た膵がんでは上昇すると推定された，われわれの症例 では認めなかったが, 糖尿病患者の血中トリプシン低 下泉が注目されており，今後の検討が必要と考える。

\section{5. ま と め}

リアグノストトリプシン RIA キットを使用検討 し,つぎのごとくの結論を得た。

(1) 標準曲線：急峻で良好な曲線が得られた。

(2) インキュベーション条件:第一反応は室温で 10-24 時間, 第二反応は室温で 3-5 時間の設定で 良好なる測定結果が得られた。

（3）再現性拉よび回収率：再現性の C.V.は10\%以 下，回収率は土3\%以内と優れていた。

（4）希釈試験：優れた希釈効果を示した。

(5) 血中トリプシンとェラスターゼ-1の相関 : $r=$ 0.889 と優れた正の相関関係を示した。

(6) 正常域および各種膵疾患の血中トリプシン值： 正常域は 100-500 ng/ml, 急性膵炎は著明なる上 昇, 慢性膵炎之糖尿病は $500 \mathrm{ng} / \mathrm{ml}$ 以下, 膵がん は 50-1 $250 \mathrm{ng} / \mathrm{ml}$ の範囲に散在する傾向にあっ た。

\section{文献}

1）中野 哲, 野田愛司：胆と膵, 7, 143-148(1986)

2）中野 哲，鈴木敏行：同 上, 7,631-649(1986)

3）早川哲夫, 近藤孝晴, 山崎嘉弘, 他: 日消誌, 76, 1513-1521 (1979)

4）金森勇雄，松尾定雄，铎口ちづ子，他：基礎と 臨床，14，2735-2740（1980）
5）金森勇雄，松尾定雄，川瀬明子，他：ホルモン 々臨床，30，101-105 (1982)

6）今村浩一郎, 木村寿成, 松本雅裕, 他：日消誌, 78, 238-245 (1981)

7）中野哲, 武田 功, 綿引 元, 他: 胆と膵, 2, 1185-1192 (1981)

\section{Abstract}

Clinical Usefulness of Trypsin Radioimmunoassay Kit. Isao KANAMORI, Satoshi NAKANO, Masakazu HURukawa, Yasuki OKumura, Chizuko HigUCHI, Mikiko YANASE and Michiteru ONOGI: Department of Radionuclear Medicine, Ohgaki Municipal Hospital, 86, Minaminokawa-machi 4chome, Ohgaki-shi 503, Japan.

From the clinical use of RIA-gnost trypsin kit, the following results were obtained.

1. Standard curve showed a steep and good curve was shown.

2. Incubation: The condition for the first incubation was set at the room temperature for 10-24 hours and that for the second incubation at the room temperature for 3-5 hours. With these settings, satisfactory results were obtained.

3. Reproducibility and recovery: The C.V. of the reproducibility and the recovery were considered superior, and the values were below $10 \%$ and $\pm 3 \%$, respectively.

4. Correlation between trypsin and serum elestase-1: An excellent positive correlation (coefficient of correlation $r=0.889$ ) was shown.

5. Serum trypsin concentration of normal and pancreatic diseases: The normal range was from 100 to $500 \mathrm{ng} / \mathrm{ml}$. Acute pancreatitis rose obviously. Diabetes mellitus and chronic pancreatitis was below $500 \mathrm{ng} / \mathrm{ml}$ and the pancreatic cancer showed a tendency to scatter in the range of $50-1250 \mathrm{ng} / \mathrm{ml}$.

The above results indicated that serum trypsin can be easily measured with high precision by using this method. Thus the method is considered useful for the diagnosis of pancreatic diseases.

(Received April 13, 1988) 